\title{
Wind Powering America Podcasts
}
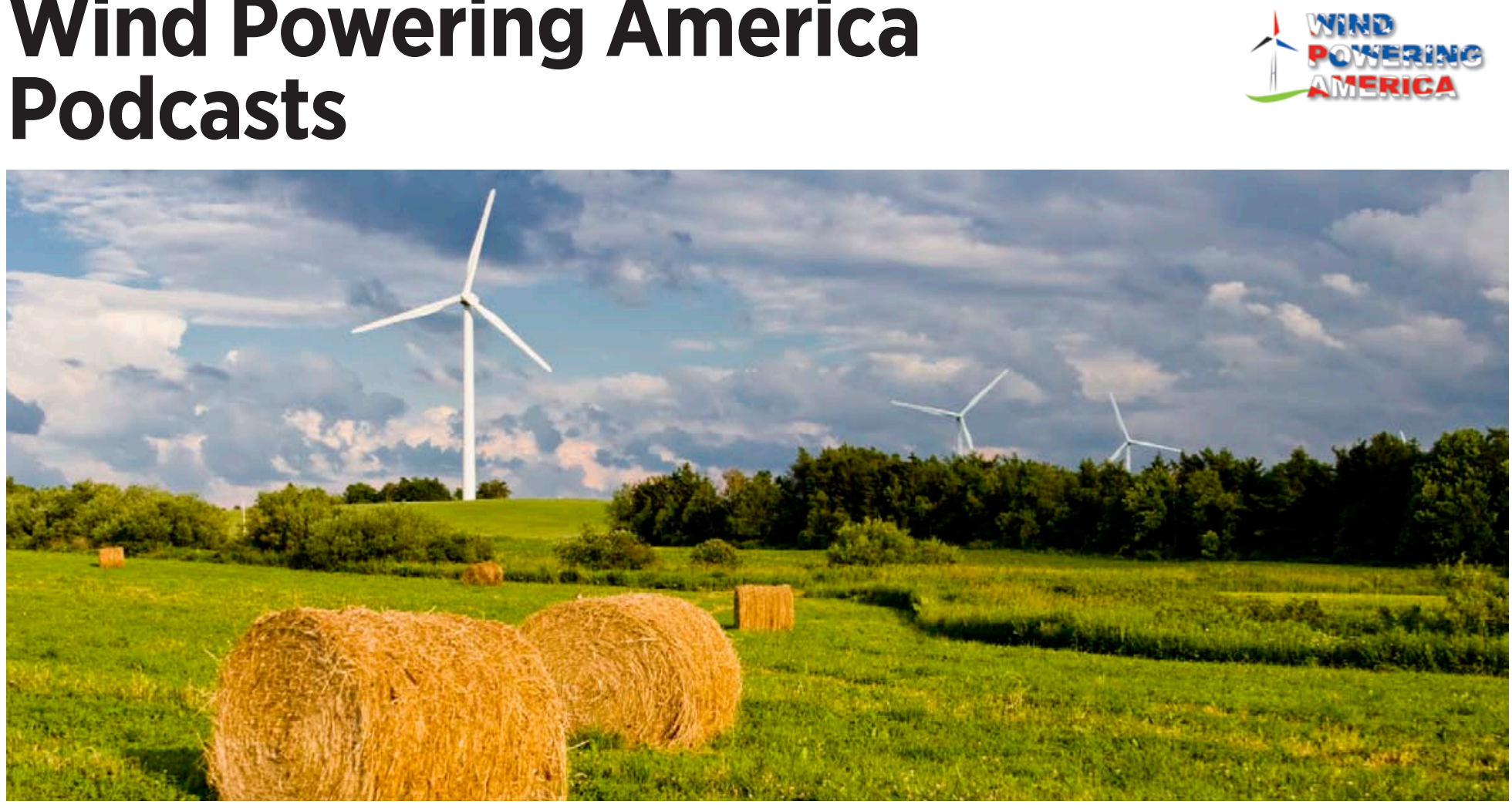


\section{Wind Powering America Podcasts}

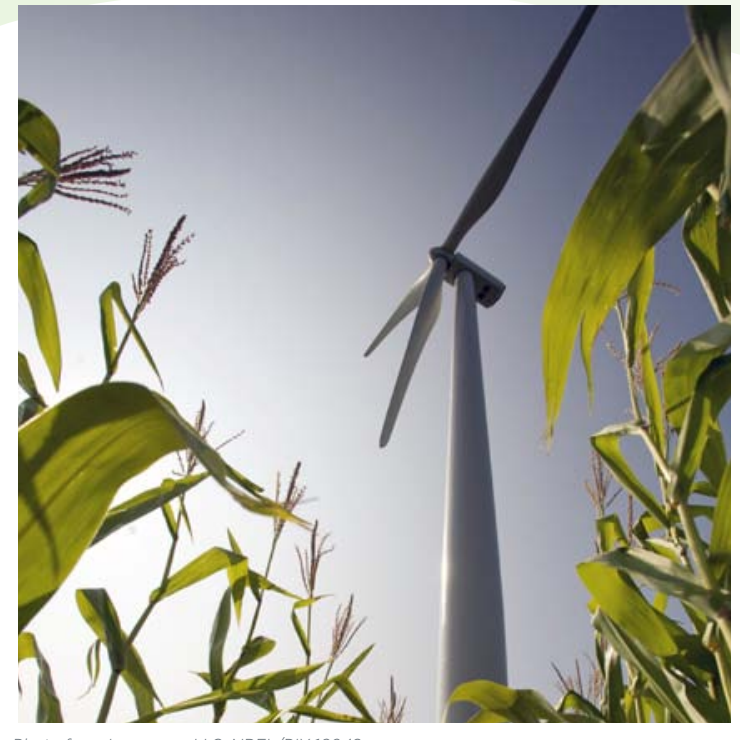

Photo from Invenergy, LLC, NREL/PIX 16042
Wind Powering America and the National Association of Farm Broadcasters produce a series of radio interviews featuring experts discussing wind energy topics. The interviews are aimed at a rural stakeholder audience and are available as podcasts. On the Wind Powering America website, you can access past interviews on topics such as:

- Keys to Local Wind Energy Development Success

- What to Know about Installing a Wind Energy System on Your Farm

- Wind Energy Development Can Revitalize Rural America.

\section{Us. Departuent of}

Energy Efficiency \&

Renewable Energy

windpoweringamerica.gov/podcasts_agricultural.asp

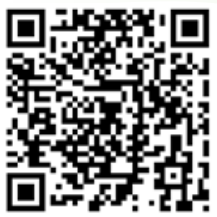

wastepape 